\title{
Reconnaissance of
}

Ground-Water Resources

in the Western Coal Field

Region, Kentucky

GEOLOGICAL SURVEY WATER-SUPPLY PAPER 1599

Prepared in cooperation with the Commonwealth of Kentucky, Department of Economic Development, and the Kentucky Geological Survey, University of Kentucky

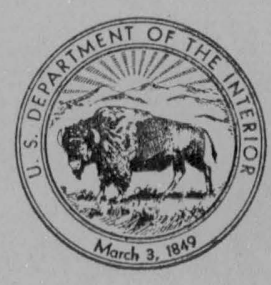




\section{Reconnaissance of}

\section{Ground-Water Resources}

in the Western Coal Field Region, Kentucky

By B W MAXWELL and R W. DEVAUL

GEOLOGICAL SURVEY WATER-SUPPLY PAPER 1599

Prepared in cooperation with the Commonwealth of Kentucky, Department of Economic Development, and the Kentucky Geological Survey, University of Kentucky

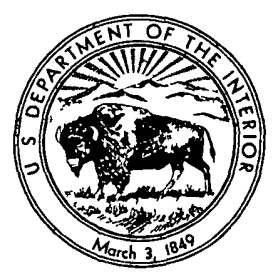




\section{UNITED STATES DEPARTMENT OF THE INTERIOR}

STEWART L. UDALL, Secretary

\section{GEOLOGICAL SURVEY}

Thomas B. Nolan, Director

The U.S. Geological Survey Library catalog card appears after page 34 


\section{CONTENTS}

Pago

Abstract.

Introduction

Purpose and scope of investigation

Location and extent of region

Previous investigations_._. 5

Method of investigation. 5

Acknowledgments $\ldots \ldots$

Geography

Topography and drainage. 6

Climate.

Economy and resources.

Geology

Stratigraphy

Structure._.

Geologic history

General hydrology

Definition of terms

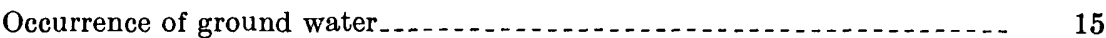

General ground-water conditions in the Western Coal Field region _- 15

Fluctuation of water levels

Water in the alluvium

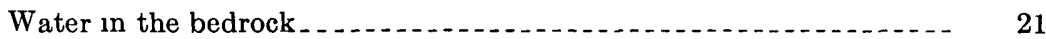

Determining the avallability of ground water at a given site $\ldots \ldots \ldots$

Suggestions for further studies.

Methods of obtaining ground water.

Springs_._.

Dug wells._.

Drilled wells.

Quality of water....

Selected references._. 33

\section{ILLUSTRATIONS}

[Plates are in pocket]

Phate 1 Generalized geologic section, southwest to northeast, of the Western Coal Field region

2 Generalized geologic section, northwest to southeast, of the Western Coal Field region

3 Generalized structure map of the No 7 coal horizon 
Figure 1 Index map of Kentucky showing progress of ground-water in-

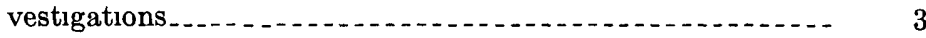

2 Index map of the Western Coal Field region ............ 4

3 Average normal temperature and precipitation at four stations in the Western Coal Field region _...

4 Generalızed geologic map of the Western Coal Field region.... 12

5 Graph showing water level in a well near Henderson and barometric pressure at Owensboro, 1957............... 16

6 Graph showing water level in a well near Henderson and stage of the Ohio River, 1953 . . .

7 Graph showing water level in a well near Nebo and precipitation at weather station 10 miles southeast, 1956 ..........

8 Percentage distribution of yields of 567 drilled wells in bedrock,

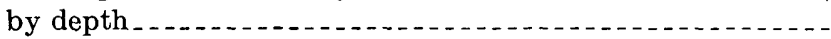

9 Graphs showing median values of dissolved constituents in ground water, by aquifers........................................

\section{TABLES}

TABLE 1 Generalized stratigraphic column of the Western Coal Field region_.............. 10

2 Correlation of data from 146 wells in alluvium _...

3 Specific capacities of wells in the Western Coal Field region _.- 21

4 Correlation of data from 567 drilled wells in bedrock...... In pocket

5 Summary of analyses of ground water in the Western Coal

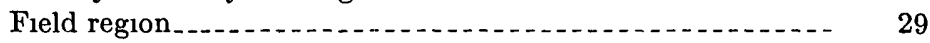

6 Significance of dissolved mineral constituents and physical properties of natural water 


\title{
RECONNAISSANGE OF GROUND-WATER RESOURGES IN THE WESTERN COAL FIELD REGION, KENTUCKY
}

\author{
By B. W. Maxwell and R. W. DevadL
}

\begin{abstract}
In the Western Coal Field region of Kentucky, water is obtained from consolıdated sedımentary rocks of Mississippian and Pennsylvanian ages and from unconsolidated sediments of Cenozolc age Pennsylvanıan rocks crop out in more than 95 percent of the area and consist of shale and sandstone interbedded with some limestone and coal The Pennsylvanian strata are divided into five formations They are, in ascending order the Caseyville sandstone and the Tradewater, Carbondale, Lisman, and Henshaw formations The Anvil Rock sandstone member of the Lisman formation and the Caseyville sandstone are the only bedrock aquifers in the region that are known to yield more than 100 gpm (gallons per minute) to wells Most bedrock wells produce enough water for a modern domestic supply, more than 500 gpd (gallons per day), and few yield so little water as to be inadequate for hand pumps and bailers, less than $100 \mathrm{gpd}$

Unconsolidated Cenozolc deposits range from latest Pliocene(?) to Recent in age and consist of clay, silt, sand, and gravel. High gravels, tentatively considered to be late Pliocene and early Pleistocene in age by McFarlan (1950, p 125), and loess of Pleistocene age are locally exposed, but nearly all of the alluvium is of late Pleistocene and Recent ages The alluvium along the Ohio River generally yields from a few hundred to as much as 1,000 gpm to single vertical wells and as much as several thousand gallons per minute to wells that have multiple horizontal screens Alluvium in the tributaries of the Ohio River generally is finer grained than that of the Ohio Valley The highest known yield from a well in the alluvium of the tributaries is $56 \mathrm{gpm}$; other wells yield enough for domestic supplies

Avalability of ground water in the region depends on the character and thickness of the aquifer penetrated, and, where the aquifer is bedrock, on the depth of the water-bearing bed, and to a certain extent on the topographic situation. Most bedrock aquifers in the Western Coal Field region are sandstone and may vary greatly in thickness and composition within short distances. The region is divided into five areas of ground-water avalability. Area 1 is confined to the Ohio Valley, most of which is underlain by relatively thick sections of sand and gravel that yield at least $50 \mathrm{gpm}$ to most wells at depths of less than 150 feet In area 2 most wells yield enough water for a modern domestic supply from depths of less than 300 feet This area includes the largest part of the bedrock outcrop in the region, some of the alluvial area along the Ohio River, and much of the alluvial areas along the larger tributaries In area 3 most wells yield enough water from depths of less than 300 feet to supply domestic needs when a hand pump is used This area covers the bedrock parts of the region that are underlain by shale, sandy shale, and limestone,
\end{abstract}


and the section where few wells are known to yield large supples of water In area 4 most wells fail to supply enough water for domestic use from depths of less than 300 feet-probably because they penetrate thick sections of unfractured shale or well-cemented sandstone. In area 5 the yield of wells is unpredictable, commonly because of faulting.

The water in the shallow bedrock aquifers of the region is mostly of the sodium bicarbonate or the calcium bicarbonate type. Saline water has been encountered at depths as shallow as $\mathbf{1 0 0}$ feet, but fresh water has been obtained at depths approaching 1,000 feet Water from the bedrock is soft to moderately hard, but it may contain undesirable amounts of uron. Most water from the alluvium is of the calcium bicarbonate type and is generally harder and contains more iron than water from the bedrock.

\section{INTRODUCTION}

\section{PURPOSE AND SCOPE OF INVESTIGATION}

To provide data for planning the use and conservation of the water resources of the Commonwealth of Kentucky, a statewide program of ground-water investigations is being made by the U.S. Geological Survey in cooperation with the Kentucky Geological Survey. Previous to July 1958, cooperation was with the Department of Economic Development of Kentucky. Investigations underway at the present time are of three general types: (a) detailed investigations of ground-water resources of small areas; (b) statewide reconnaissance to locate sources warranting detailed study as potential water supplies for large-scale public, industrial, and agricultural demands; and (c) statewide reconnaissance investigations of groundwater resources for general use.

This investigation is of the third type and is one of a series of five which will cover the Commonwealth. This report provides general information on the availability of ground water in the Western Coal Field region of Kentucky.

\section{LOCATION AND EXTENT OF REGION}

For convenience in reconnaissance study of the ground-water resources, the Commonwealth of Kentucky has been divided into five regions of more or less distinctive geology and physiography, as follows: Eastern Coal Field, Bluegrass, Mississippian Plateau, Western Coal Field, and Jackson Purchase (fig. 1). The boundaries of the regions are drawn on the county lines, which approximate, but do not coincide exactly with the geologic and physiographic boundaries.

The Western Coal Field region, as defined in this report, includes about 4,500 square miles in the western part of the Commonwealth, and consists of 10 counties: Butler, Daviess, Hancock, Henderson, Hopkins, McLean, Muhlenberg, Ohio, Union, and Webster (fig. 2). 


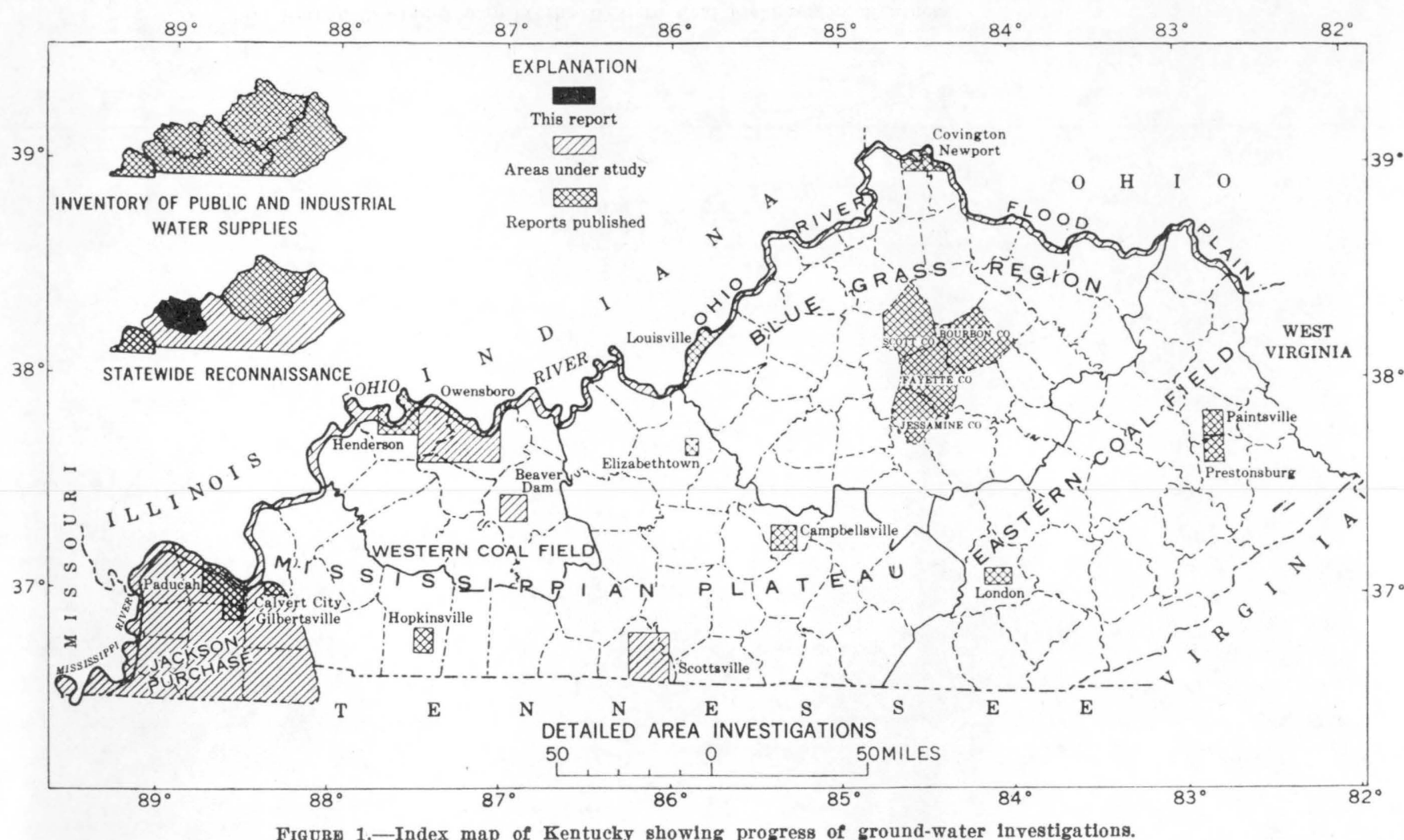

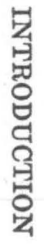




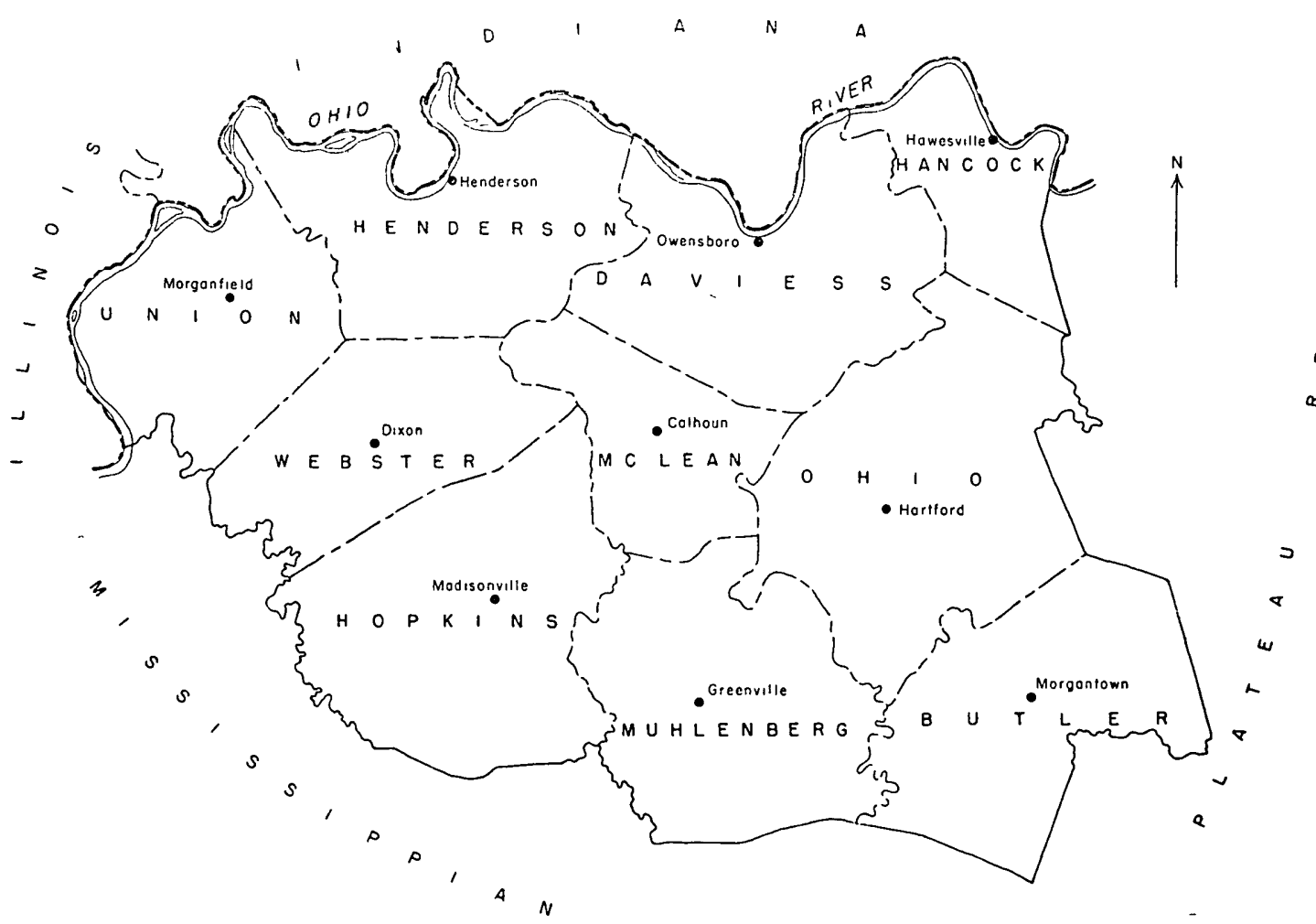


On the north and west, the region is separated from the States of Indiana and Illinois by the Ohio River, and on the east, south, and southwest it is bounded by the Mississippian Plateau region. The U.S. Census Bureau reported a total population in 1950 of almost 238,000 .

\section{PREVIOUS INVESTIGATIONS}

Ground-water conditions and geology of the Henderson area are described in a report by Harvey (1956). Information on the public and industrial water supplies of the region is included in a report by Maxwell (1954). The deep-channel and alluvial deposits of the Ohio Valley in Kentucky are described in a report by Walker (1957).

\section{METHOD OF INVESTIGATION}

The fieldwork for this investigation was done by E. J. Harvey, B. W Maxwell, and R. W Devaul from 1950 to 1954. Some work was done in the Hartford quadrangle in 1948 by E. G. Otton.

Fieldwork consisted chiefly of an inventory of wells and some springs and a study of the nature of the openings in the rocks that affect storage and movement of ground water. Information was obtained on water wells, springs, coal- and oll-test holes, and bridge borings. Well depths; depths to water; pumping levels, nature, depth, and thickness of the aquifers; and the quality of the water were noted A report on the permanence and adequacy of the water supply from each well was obtained from the owner whenever possible Samples of water from representative supplies were collected for chemical analysis. Logs of wells were obtained from drillers and well owners, and samples of rock from wells being drilled during the course of the investigation were examined. Electric logs of oll-test holes were used extensively in subsurface correlation of rock strata.

Water-level measurements were made in several wells by means of a steel tape or a recording gage to determine the nature and amount of the water-level fluctuations

A pumping test was made at Beaver Dam in 1948 by M. I. Rorabaugh and E. G. Otton. Others were made by E. J. Harvey, B. W. Maxwell, and R. W. Devaul during the investigation. W. H. Walker made several specific-capacity tests during 1954.

Information obtained in the well-and-spring inventory is summarized by well symbol and explained on the water-availability maps in the atlases of the hydrologic investigations series covering the Western Coal Field region (Maxwell and Devaul, 1962a, b, c, and Devaul and Maxwell 1962a, b).

602624-61-2 
The geologic maps accompanying these atlases were adapted from existing county and quadrangle geologic maps published by the Kentucky Geological Survey. In some cases the units mapped in one county were not equivalent to the units mapped in an adjacent county. Such differences are noted on the geologic maps by changes in pattern and symbol.

\section{ACRNOWLEDGMENTS}

The reconnaissance was aided greatly by cooperation and interest of well owners and well drillers, county agents, mining companies, and oilfield operators. The Kentucky Geological Survey made available its library and files of well logs and cuttings. The general geologic information included in this report is based largely on maps and reports of the Kentucky Geological Survey. A. C. McFarlan, of the Kentucky Geological Survey, cooperated in the compilation of the stratigraphic column of the region.

\section{GEOGRAPHY}

The Western Coal Field region of Kentucky is a part of the Illinois-Indiana-Kentucky basin, or the Eastern Interior basin (Eardley, 1951, p. 32), and is bordered on the east, south, and southwest by the Mississippian Plateau region.

\section{TOPOGRAPHY AND DRAINAGE}

Most of the region is a rolling upland 400 to 550 feet above sea level. Near the east, south, and southwest boundaries of the region is a belt of rugged hills, as much as 839 feet in altitude, which generally coincides with the outcrop of the Caseyville sandstone and the lower part of the Tradewater formation. Another belt of hills lies along the Shawneetown-Rough Creek fault zone, which extends westward across the central part of the region. Extensive flood plains and alluvial terraces of low relief, ranging in altitude from 340 to 430 feet, border the Ohio and Green Rivers and their tributaries.

The alluvial terraces and flood plain on the Kentucky side of the Ohio River form the entire north and northwest boundaries of the Western Coal Field region. The width of the alluvial deposits on the Kentucky side of the river ranges from very narrow at Hawesville, where the river flows close to the valley wall, to almost 10 miles just north of Uniontown.

The entire Western Coal Field region is drained by the Ohio River and its tributaries. The Green River, flowing across the region in a northwestward direction toward the Ohio, and its tributaries, the Pond, Mud, and Rough Rivers and Panther Creek, drain about 65 
percent of the area. The Tradewater River, which forms the approximate southwest boundary of the Western Coal Freld, drains about 15 percent of the area. The remainder is drained by the Ohio River directly or through small tributaries.

\section{Climate}

The climate of this region is of the humid continental type. The prevalling winds are from the south. The average annual temperature is about $57^{\circ} \mathrm{F}$. At four stations the average January temperature is about $36^{\circ} \mathrm{F}$, and temperatures below $0^{\circ} \mathbf{F}$ occur occasionally. The average $\mathrm{July}$ temperature is about $78^{\circ} \mathrm{F}$, and temperatures above $100^{\circ} \mathrm{F}$ occur occasionally during the summer. The growing season between klling frosts ranges from 169 to 250 days and averages 210 days. The average annual precipitation is about 44 inches. Precipitation normally is fairly well distributed throughout the year. Most of the precipitation occurs as rainfall; snowfall is scanty and infrequent. Figure 3 shows the average normal monthly temperature and precipitation at four stations in the Western Coal Field region.

For a period of about 3 years, from the spring of 1952 through the winter of 1954-55, the Western Coal Field region, as well as other
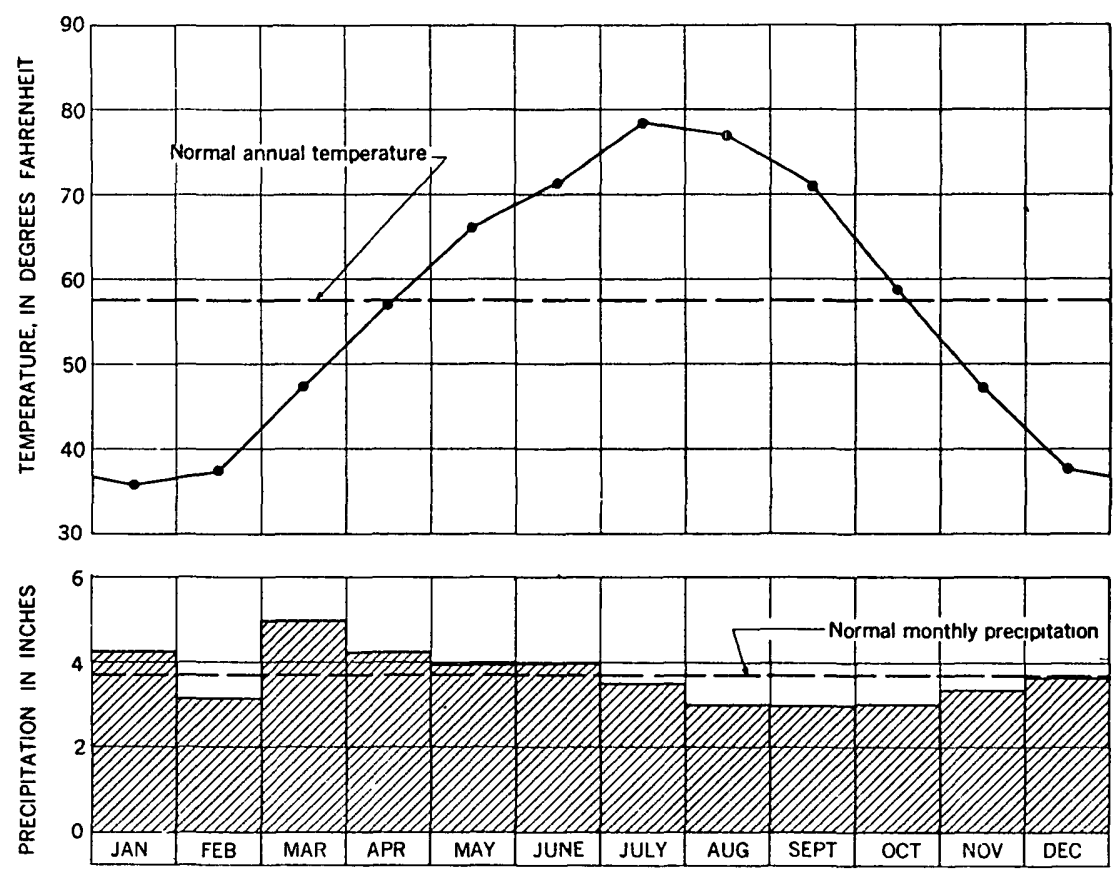

Figdro 3-Average normal temperature and precipitation at four stations in the Western Coal Field region, Kentucky (from records of the $U$ S Weather Bureau) 
sections of Kentucky, experienced considerably less than normal rainfall and higher than average temperatures The effects of the dry period were not felt appreciably unt1l 1953, for which year the Weather Bureau records show a precipitation deficiency of 7 to nearly 15 inches at four stations in the region. The average annual temperature during the 3 -year period was about $1.6^{\circ} \mathrm{F}$ above normal. In the Henderson and Greenville areas precipitation was deficient through 1955 Many wells and springs are reported to have gone dry for the first time during the summer and fall of 1953 and 1954

\section{ECONOMY AND RESOURCES}

The economy of the Western Coal Field region is dependent chiefly on farming, mining, and petroleum production. Most of the large and prosperous farms are on alluvial terraces of the larger streams. Corn, soybeans, tobacco, and cattle are the chief farm products. On the rolling uplands the farms are generally smaller, and fruit farming, cattle raising, and dairying are the chief activities. The hilly areas near the boundaries of the region and the dissected areas bordering the rivers are too rugged for large-scale farming, and the cultivated areas are small There is some production of timber, mostly for local use

Irrigation of crops is becoming increasingly common in this region, and about 25 irrigation systems that use ground water are known to have been installed from 1953 to 1956 . These are all in the alluvium along the Ohio River, but some small systems may utllize water from ponds and small streams in the interior of the region. Rates of pumping from wells range from 10 to $1,000 \mathrm{gpm}$ (gallons per minute), and the acreage being irrigated ranges generally from 2 to 125 acres per well.

Coal is produced in all of the 10 counties, but most of the production at the time of this investigation (1958) was in Hopkins and Muhlenberg Counties. In 1954 more than 22 million tons of bituminous coal were mined (S1sk, 1954). The coal reserves are large The Corps of Engineers has built two large locks, at dams 1 and 2 on the Green River, to provide access to the interior of the region for shipment of coal in large barges

Oll also is produced in each of the 10 counties. The production in 1954 was more than 11 million barrels, 82 percent of the Kentucky total for that year; Henderson and Union Counties were the largest producers (Sisk, 1954).

Several firms manufacture tile and brick from clay deposits Sand and gravel are dredged from the Ohıo River and recovered from openpit operations, and limestone is quarried in a few places. Other 
industries include the production of distılled beverages, chemicals, food products, furniture, clothing, electrical equipment, plastıc products, and steel.

\section{GEOLOGY}

The consolidated rocks exposed in the Western Coal Field region, as defined in this report, are of sedimentary origin and of late Mississippian and Pennsylvanian age (table 1). Pennsylvanian rocks crop out in more than 95 percent of the area; they consist for the most part of shale and sandstone interbedded with minor amounts of limestone and coal. Along the eastern and southern borders and along the Shawneetown-Rough Creek fault zone limestone, sandstone, and shale of Mississippian age crop out. As the region is a part of a large basin, the rocks dip gently inward from the eastern, southern, and western borders.

\section{STRATIGRAPHY}

As the Mississippian rocks are exposed in only a small part of the region, they are treated as a unit in the text of the present report. The overlying Pennsylvanian rocks are divided into five formations in ascending order the Caseyville sandstone and the Tradewater, Carbondale, Lisman, and Henshaw formations. Unconsolıdated deposits of Pliocene $\left(^{2}\right)$ and Pleistocene, Pleistocene, and Recent age consisting of clay, silt, sand, and gravel represent the Cenozoic era in the region.

Paleozoic rocks extend to a depth of at least 6,300 feet beneath the base of the Pennsylvanian, as evidenced by an oll-test hole near Sebree, Webster County (Freeman, 1951, p. 133-139).

The areal extent and geologic characteristics of the consolidated and unconsolidated rocks of the region are shown in the generalized geologic map, (fig. 4).

\section{STRUCTURE}

The Western Coal Field region of Kentucky is the southern part of a structural basin centering in Illinois and extending into Kentucky and Indiana. From the boundaries on the east, south, and southwest the rocks dip gently inward. This simple structure is complicated by two major features: the Moorman syncline, which extends northwestward from Butler County through Union County and includes the structurally lowest part of the Western Coal Field; and the Shawneetown-Rough Creek fault zone, which is north of the Moorman syncline and extends generally westward across the entire region Along the fault zone the rocks are broken into a complex pattern by both parallel and cross faults. The displacement along the fault zone, exceeding 1,000 feet in places, brings limestone of Late Missis- 
TABLE 1 -Generalized stratigraphic column of the Western Coal Field regron, Kentucky

\begin{tabular}{|c|c|c|c|c|c|c|}
\hline & System & Series & Group & \multicolumn{2}{|c|}{ Formation } & Member \\
\hline & \multirow{2}{*}{ Quaternary } & \multirow{2}{*}{$\begin{array}{l}\text { Recent and } \\
\text { Pleistocene }\end{array}$} & & \multicolumn{2}{|c|}{ Union formation 1} & \\
\hline & & & & \multicolumn{2}{|c|}{ Alluvium and loess } & \\
\hline & $\begin{array}{l}\text { Quaternary and } \\
\text { Tertiary(?) }\end{array}$ & $\begin{array}{l}\text { Plelstocene and } \\
\text { Plocene(?) }\end{array}$ & & \multicolumn{2}{|l|}{ Gravel } & \\
\hline \multirow{6}{*}{ 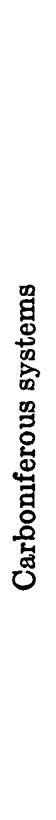 } & \multirow{6}{*}{ Pennsylvanıan } & & \multirow[t]{2}{*}{ McLeansboro } & \multicolumn{2}{|c|}{ Henshaw formation } & $\begin{array}{l}\text { Mt Gllead sandstone }{ }^{2} \\
\text { Mt Gilead shale }{ }^{2} \\
\text { Vanderburg sandstone }{ }^{1} \\
\text { Bald Hill shale }{ }^{1} \\
\text { Dixon sandstone }{ }^{1}\end{array}$ \\
\hline & & & & \multicolumn{2}{|c|}{ Lisman formation } & $\begin{array}{l}\text { Carthage limestone }{ }^{3} \\
\text { Madisonvile limestone member } \\
\text { Anvil Rock sandstone member } \\
\text { Providence limestone member }\end{array}$ \\
\hline & & & & \multicolumn{2}{|c|}{ Carbondale formation } & $\begin{array}{l}\text { Upper sandstone member } \\
\text { Pleasantview(?) sandstone } \\
\text { Sebree sandstone }^{1}\end{array}$ \\
\hline & & & & \multicolumn{2}{|c|}{ Tradewater formation } & $\begin{array}{l}\text { Stonefort limestone member } \\
\text { Curlew sandstone }{ }^{3} \\
\text { Unnamed limestone member } \\
\text { Curlew limestone }{ }^{5}=\text { Fusulina(?) chert } \\
\text { (Ohio County) = Lead Creek(?) } \\
\text { limestone }{ }^{6} \text { (Hancock County) } \\
\text { Aberdeen sandstone }{ }^{7}\end{array}$ \\
\hline & & & & & \multirow{2}{*}{ 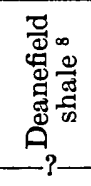 } & $\begin{array}{l}\text { Finnie sandstone }{ }^{\prime} \\
\text { Grindstaff sandstone member }\end{array}$ \\
\hline & & & & $\begin{array}{l}\text { Caseyville } \\
\text { sandstone }\end{array}$ & & $\begin{array}{l}\text { Bee Springs sandstone }{ }^{\circ} \\
\text { Lower conglomerate member }\end{array}$ \\
\hline
\end{tabular}




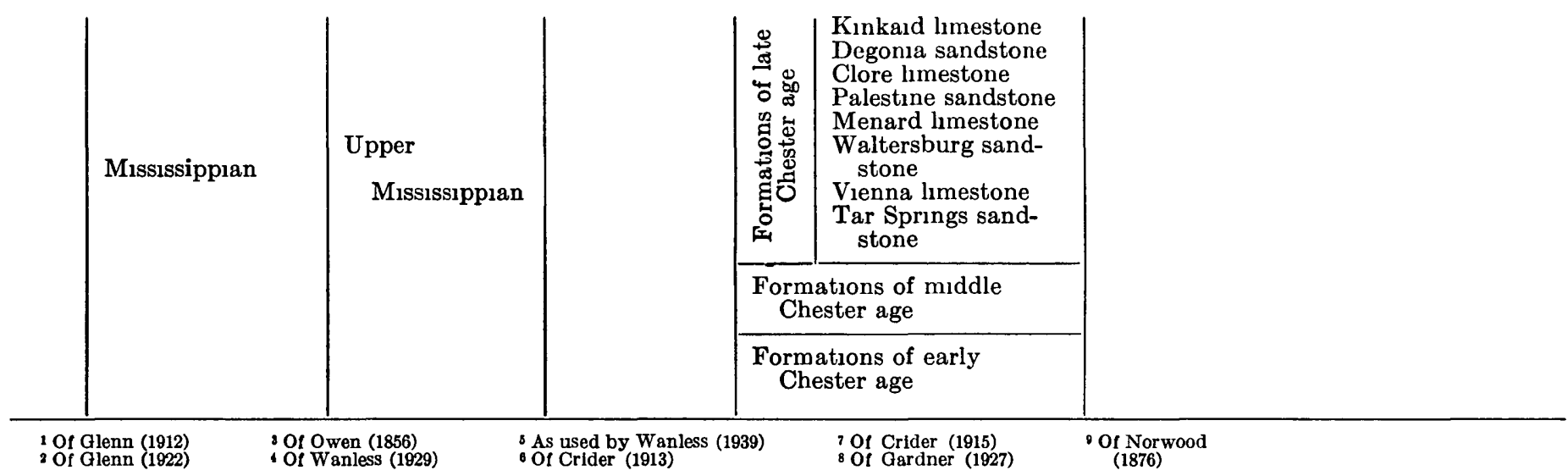




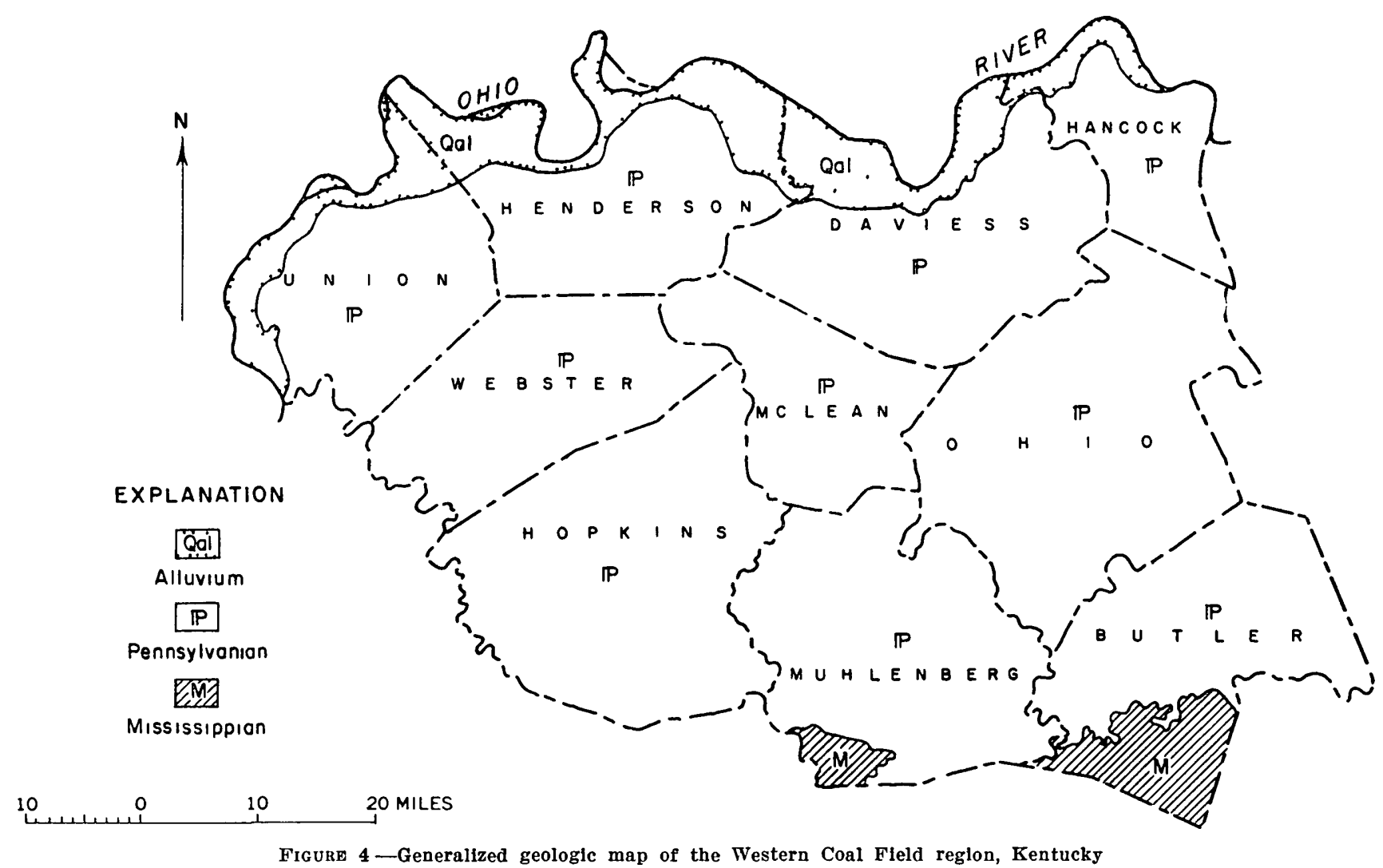


sippian age in contact with rocks of the Lisman formation of Pennsylvanian age. Most of the faults are high angle normal and reverse faults.

Eastward-trending faults are prominent in southern Hopkins and Muhlenberg Counties; some extend eastward into Butler County. A set of northeastward-trending faults includes the Indian Creek and the Hawesville faults in Hancock County, the Curdsville and Sorgho faults of Daviess County, a fault west of Geneva in Henderson County, and one passing through Uniontown in Unıon County The location of the major structural features of the region is shown on the map on plate 1 and on plate 3 The general structural features are shown also in section $A-A^{\prime}$ and $B-B^{\prime}$, plates 1 and 2. Plate 3 is a generalized structure contour map of the top of the No. 7 coal horlzon. Most of the contacts were interpreted from electric logs.

\section{GEOLOGIC HISTORY}

During the early part of the Paleozoic era, western Kentucky was repeatedly flooded by the sea Although there were major interruptions in marine deposition and undoubtedly some continental deposition, practically all the early Paleozorc deposits that remain are of marne origin. These deposits, now consolıdated, consist of limestone, dolomite, sandstone, and shale. Later, in the Mississippian period, marine inundations became less frequent, and the close of the Mississippian period was marked by the emergence of this part of the continent. Streams carried away part of the rocks and cut channels several hundred feet deep into the Upper Mississippian rocks, producing a surface of considerable relief On this surface the Lower Pennsylvanian sedıments, mostly contınental in origin, were deposited During Pennsylvanian time at least 2,750 feet of sedıments was deposited in the deeper part of the basin (Wanless, 1939). Great thicknesses of sand and sandy gravel were deposited in deep channels in the early part of the period, later, deposits which formed coal, shale, and thin limestone beds became more prominent

Most of the faulting occurred after the close of the Pennsylvanian period. The post-Pennsylvanian faults intersect all the consolidated strata exposed in the Western Coal Field region. Rocks of Permian and Mesozolc age are unknown in the region, although some may have been deposited and later removed by erosion

High-level gravel beds are found at altitudes up to 625 feet These gravel patches probably are remnants of more widespread deposits which were laid down by streams before Pleistocene glaciation.

During the Pleistocene epoch the Ohio River cut its bedrock channel to its present depth, and glacial-outwash deposits of both $602624-61-3$ 
Illinoian and Wisconsin age were deposited in the channel. The glacial outwash deposits in the Ohio Valley are generally coarser than the alluvium in tributary valleys. Blanketing the bluffs along the south side of the Ohio, and for some distance south of the river, is a thick deposit of windblown loess consisting of silt and fine sand The loess was derived from the broad flat flood plains along the river Recent alluvium occurs along the present streams (Walker, 1957)

\section{GENERAL HYDROLOGY}

The primary purpose of this report is to provide information on the occurrence of ground water for residents of the region. Therefore, technical terms are restricted to those considered essential to the understanding of the occurrence of ground water. The following definitions are based largely on those given by Meinzer (1923a, b). A few terms, which are not given in the following list, are defined where they are used in the text

\section{DEFINITION OF TERMS}

Aquifer -A formation, group of formations, or part of a formation that is water yielding

Aquifer, confined-Aquifer which is overlain by a confining bed and which contains water that is under sufficient pressure to rise above the bottom of the confining bed Also called artesian aquifer.

Aquifer, semiconfined-Aquifer overlain by a confining bed which itself is somewhat permeable and may act as an aquifer and through which water may move either into or out of the lower aquifer.

Aquifer, unconfined -Aquifer which is not overlain by a confining bed and in which, therefore, the water table is free to rise and fall. Also called water-table aquifer

Discharge, ground-water.-Discharge of water from an aquifer, either by natural means such as evapotranspiration and flow from seeps and springs, or by artificial means such as pumping from wells

Drawdown-Lowering of the water level in a well as a result of withdrawal of water.

Evapotranspiration - Total discharge of water to the air by direct evaporation and plant transpiration.

Permeability - The capacity of earth materials to transmit water under pressure In general, the larger the connected pore spaces or other openings in the material the greater the permeability

Piezometro surface - The imaginary surface defined by the level to which water will rise in wells tapping a confined aquifer. Is 
analogous to the water table in that its shape and slope are indicative of the direction and relative rate of movement of water in the aquifer

Porosity - The ratio of the volume of the openings to the total volume of a rock or soll A high porosity does not necessarily indicate a high permeability

Recharge, ground-water-Addition of water to an aquifer by infiltration of precipitation through the soll, by flow from streams or other bodies of surface water, by flow of surface water through sinkholes, or by flow of ground water from another aquifer.

Saline water.-Saline water has been defined in some reports as water containing more than $1,000 \mathrm{ppm}$ (parts per million) of dissolved solıds. In some areas, however, no better water is avallable and water containing more than $1,000 \mathrm{ppm}$ is not considered unpotable, on the other hand, some water contaming less than 1,000 $\mathrm{ppm}$, but having a high proportion of sodium and chloride, has a salty taste

Specific capacity - The rate of yield of a well per unit of drawdown, generally expressed in gallons per minute per foot of drawdown at the end of a specified period of discharge Not an exact quantity, as drawdown increases with time Gives an approximate indication of how much water a well can yıeld

Water table - The upper surface of the zone of saturation except where that surface is formed by impermeable material.

Zone of saturation - The zone in which the openings in the rocks are filled with water under hydrostatic pressure.

\section{OCCURRENCE OF GROUND WATER}

\section{GENERAL GROUND-WATER CONDITIONS IN THE WESTERN COAL FIELD REGION}

Water that enters the aquifers of the Western Coal Field comes mostly from precipitation which falls directly on the land area and in part finds its way to the water table Some ground water is recharged by influent seepage from streams that flow across outcrop areas Ground water exists in two different environments, the consolidated bedrock and the sand and gravel in the valleys of the Ohıo River and its tributaries.

In medium-grained poorly cemented sandstone, such as the Caseyville in places, the yield of wells may be derived largely from intergranular openings (pores), although water from fractures may increase the yield In sandstones that are fine grained, shaly, or well cemented, intergranular openings may yıeld very little water dnectly to wells In these rocks, most successful wells obtain water 
from fractures. Generally these openings are comparatively large and numerous at shallow depth and are smaller and more widely spaced at greater depth.

In limestone, fractures may be enlarged by solution and may yield large quantities of water, but in the Western Coal Field region few wells are developed in limestone, and none of these is known to yield large amounts of water.

In unconsolidated deposits, such as the sand and gravel along the Ohio River and its tributaries, the yield of wells is derived entirely from intergranular openings The amount of water obtained depends largely upon the size, shape, and grading of the particles and the thickness of the aquifer.

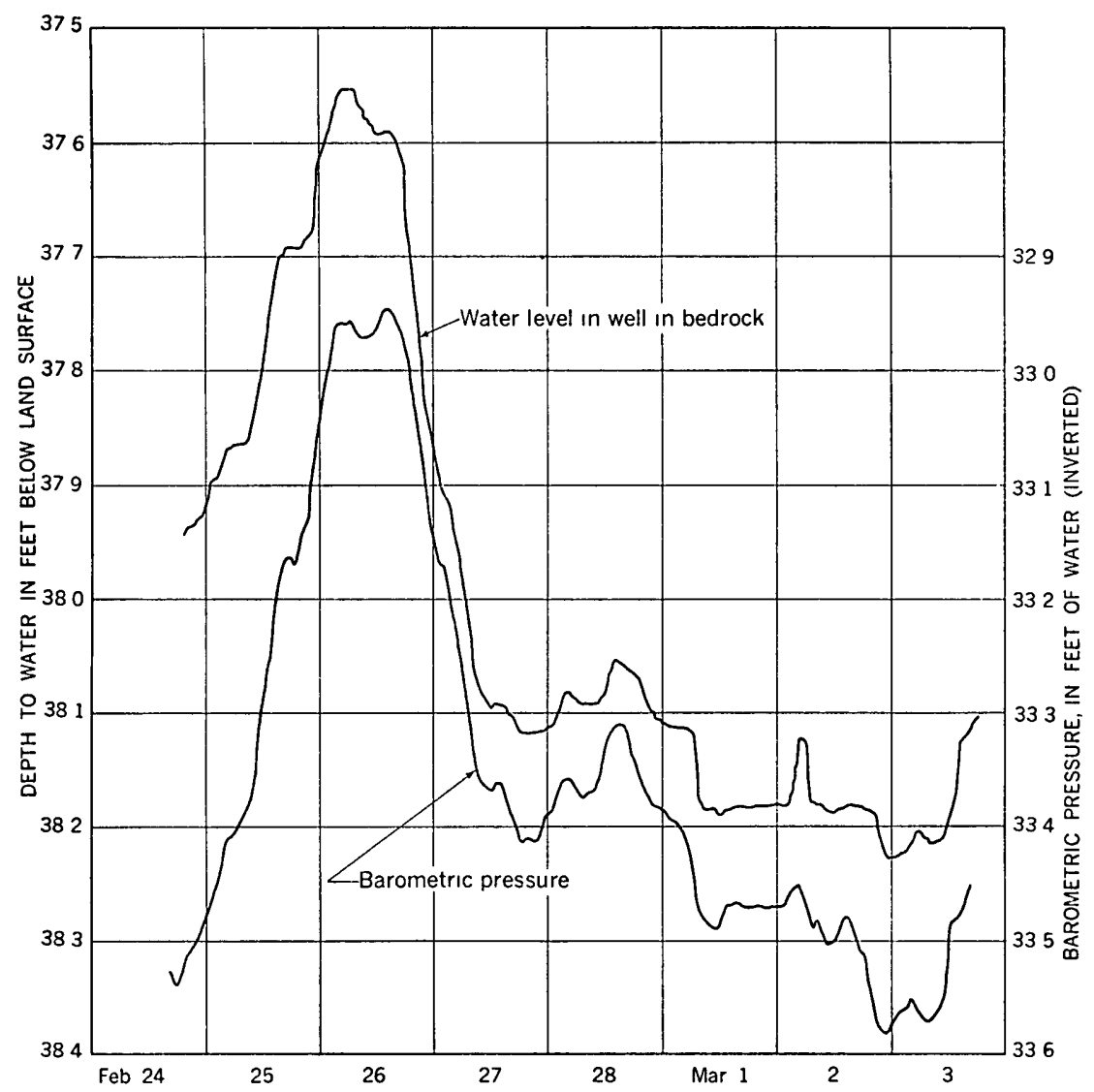

Fiaune 5-Graph showing water level in a well near Henderson, Ky, and barometric pressure at Owensboro, Ky, 1957 


\section{FLUCTUATION OF WATER LEVELS}

The position of the water table is related directly to the amount of ground water in storage. Therefore, fluctuations of water levels in wells are an indication of changes in ground-water storage Some of the more common causes of changes in water levels in wells in the Western Coal Field region are changes in barometric pressure, changes in stage of a nearby stream, and differences in rate of recharge due to variations in local precipitation The effect of local precipitation is most apparent in the winter and early spring when the soll-moisture deficiency which accumulated during the growing season has been overcome.

Figure 5 is a graph showing fluctuations of the water level in a well penetrating a confined bedrock aquifer near Henderson, Ky., caused by changes in barometric pressure, as recorded in Owensboro, Ky. This well, which has a high barometric efficiency, is drilled in the Anvil Rock sandstone member of the Lisman formation.

Figure 6 is a graph showing the fluctuation of the Ohio River and the water level of a nearby well in alluvium near Henderson, Ky

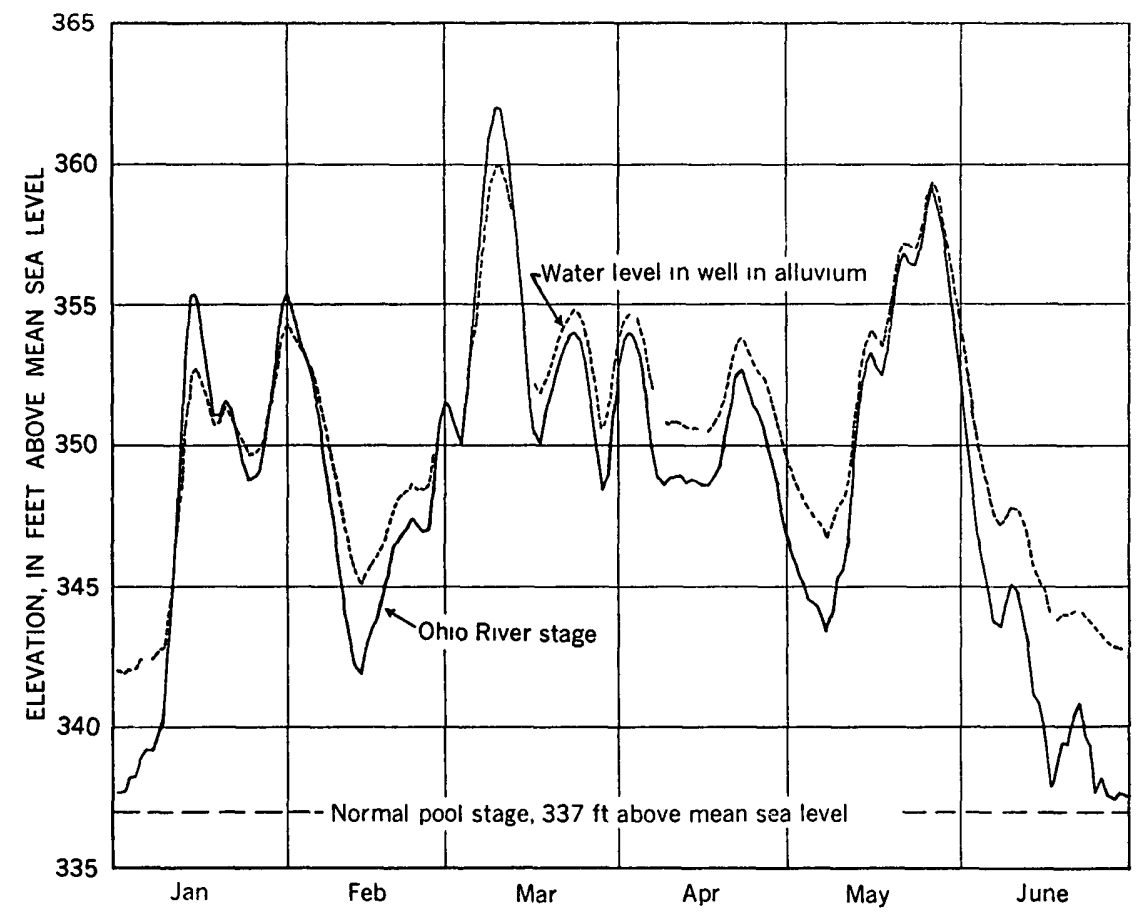

Figure 6-Graph showing water level in a well near Henderson, $\mathrm{Ky}$, and stage of the Ohlo River, 1953 
The changes in water level in the well are very similar to, although not quite as large as, the changes in river stage, also, the changes in the well occur at almost the same time as the changes in river stage

Figure 7 shows changes in water level in a well in bedrock caused by recharge from local precipitation. The well is drilled into the Lisman formation and normally is a water-table well. In the early spring however, when the ground is saturated with water, the well shows fluctuations caused by changes in barometric pressure As the weather station is 10 miles to the southeast, the changes in water level do not always correspond to the amount of precipitation recorded there. Also, minor amounts of precipitation do not seem to affect the water level in the well.

\section{WATER IN THE ALLUVIUM}

The alluvium along the Ohio River in the Western Coal Field region includes about 300 to 350 square miles, and the total area along the major tributaries is at least as great. Although this represents only a small part of the total area of the region, the alluvium is the source of about 90 percent of the ground water pumped for public and industrial supplies, and about 66 percent of all water pumped for public and industrial supplies from both ground and surface sources (Maxwell, 1954). Most of the water is pumped from the alluvium along the Ohıo River, the greatest potential source of ground water for future industrial, municipal, and agricultural development

The alluvium along the Ohio River, except where it is thin or composed of silt and clay, will yield at least enough water for domestic and farm use In much of the area, single vertical wells will yield from a few hundred to as much as 1,000 gpm. Special installations, such as wells having multiple horizontal screens, may yield several thousand gallons per minute. Two such collector-type wells near Henderson yield 3,000 to 4,000 gpm each at most times (Harvey, 1956). Even higher yields are obtained when the river stage is high and the water is warm. Such installations and also some of the highcapacity single vertical wells close to the river depend to a large extent on induced infiltration of river water Several irrigation systems producing more than $400 \mathrm{gpm}$ have been developed by connecting two or three 4-inch driven wells spaced about 15 feet apart and operating them as a single unit

Alluvium in the tributaries of the Ohio is generally finer grained than that of the Ohio Valley and consists of clay, silt, fine sand, and a small amount of gravel. Gravel has been penetrated in several wells along the Green River, but the extent of these deposits is not known. The highest known yield from any well in the alluvium of 

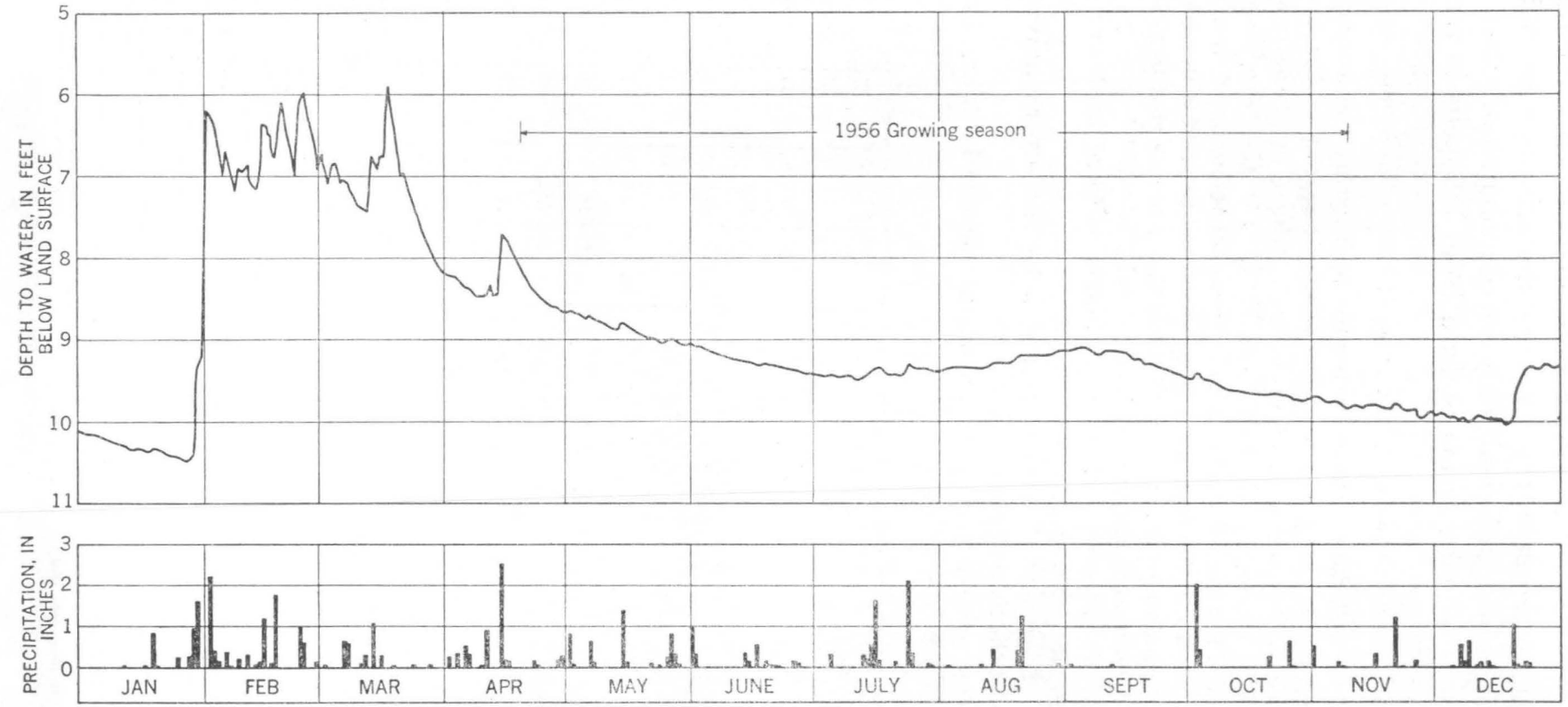

Figure 7.-Graph showing water level in a well near Nebo, Ky., and precipitation at a weather station 10 miles southeast, 1956. 
the tributaries is $56 \mathrm{gpm}$. Other wells yield enough for domestic supplies. The alluvium in the smaller tributaries is commonly thin and very fine grained and yields only small amounts of water.

Table 2 shows the correlation of data from 146 wells in alluvium.

TABLE 2-Cor relatıon of ata from 146 wells in alluvıum

Any two items of well data may be correlated by locating the number in the square formed by the intersection of the column and row of the two items Hach such number is the number of wells in which the two items occul simultaneously Example 15 wells are 75 to 150 feet deep, and were reported to yield water containing objectionable amounts of iron, or, of 34 wells that are 75 to $\mathbf{1 5 0}$ feet deep, 15 are reported to yield water containing objectionable amounts of iron, or, of 35 wells that are reported to yield water containing objectionable amounts of iron, 15 are 75 to 150 feet deep

The sum of all numbers in each large rectangle enclosed by heavy lines is equal to the number of wells in consideration

The sum of each column of numbers in rectangles enclosed by heavy lines is in the square at the base of each column

The sum of each row of numbers in rectangles enclosed by heavy lines is in the square to the left of each row

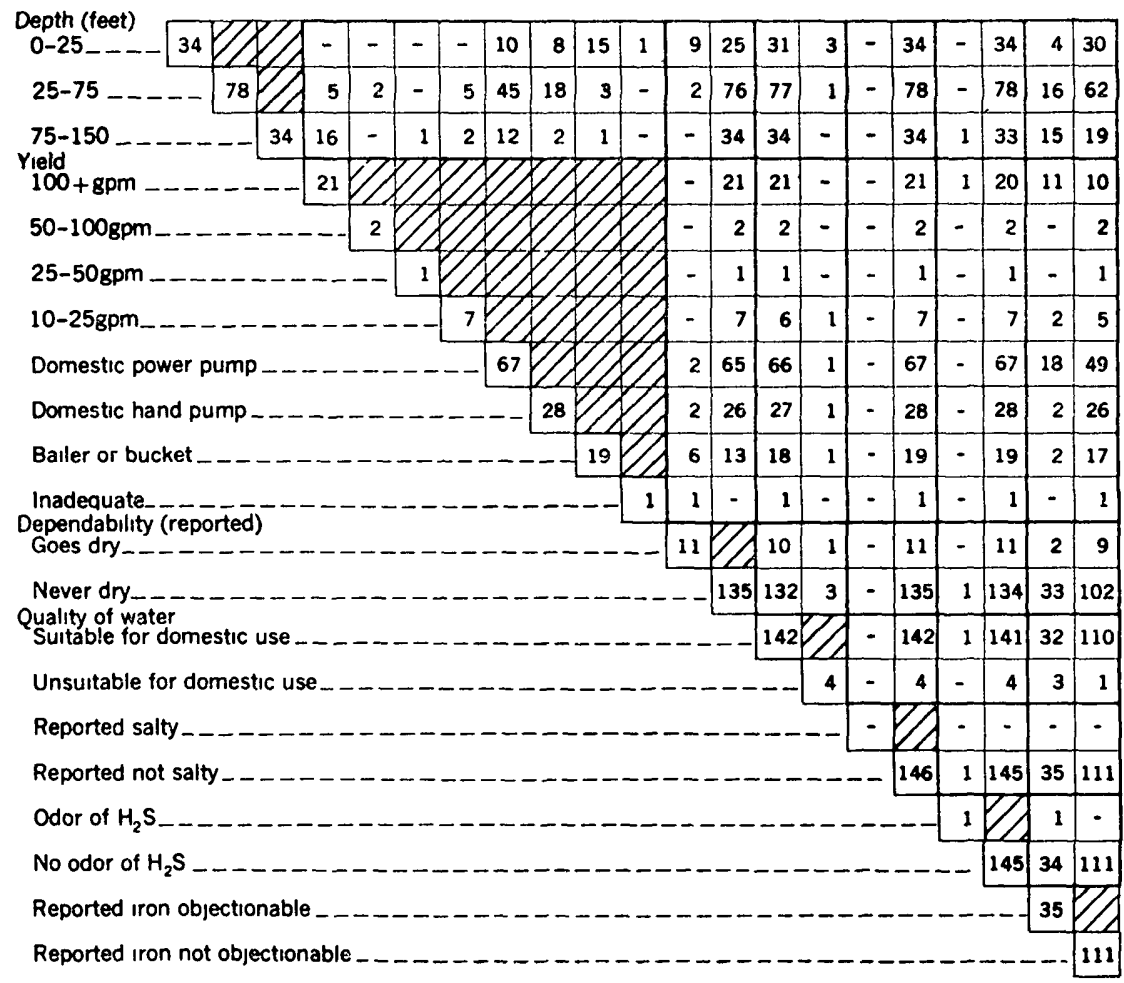


WATER IN THE BEDROCK

The only bedrock aquifers in the Western Coal Field region that are known to produce more than $100 \mathrm{gpm}$ are the Anvil Rock sandstone member of the Lisman formation and the Caseyville sandstone. Yields as much as $250 \mathrm{gpm}$ have been reported from the Caseyville, although the average is much less. Generally the Anvil Rock sandstone member yields less than $20 \mathrm{gpm}$. The other bedrock aquifers in the Western Coal Field region generally yield considerably smaller quantities of water than the Caseyville; $20 \mathrm{gpm}$ seems to be about the maximum amount that can be expected, and commonly much less is obtained with constant pumping. Generally, more than half of the bedrock wells will produce enough water for modern domestic use, and a large number are equipped for such use. Few of the wells yield so little water as to be inadequate for hand pumps and ballers. Less than 3 percent of the wells are reported to have gone dry at any time, and most of these ether were orginally inadequate or produced only small amounts of water. Some wells are reported to go dry when the water level drops below the intake of the pump; many such wells would yield sufficient water if the pump intakes were set deeper. Most of the unsuccessful wells are dug wells or drilled wells less than 75 feet deep. Table 3. shows the specific capacities of 11 wells in

TABLE 3-Specific capacities of wells in the Western Coal Field region

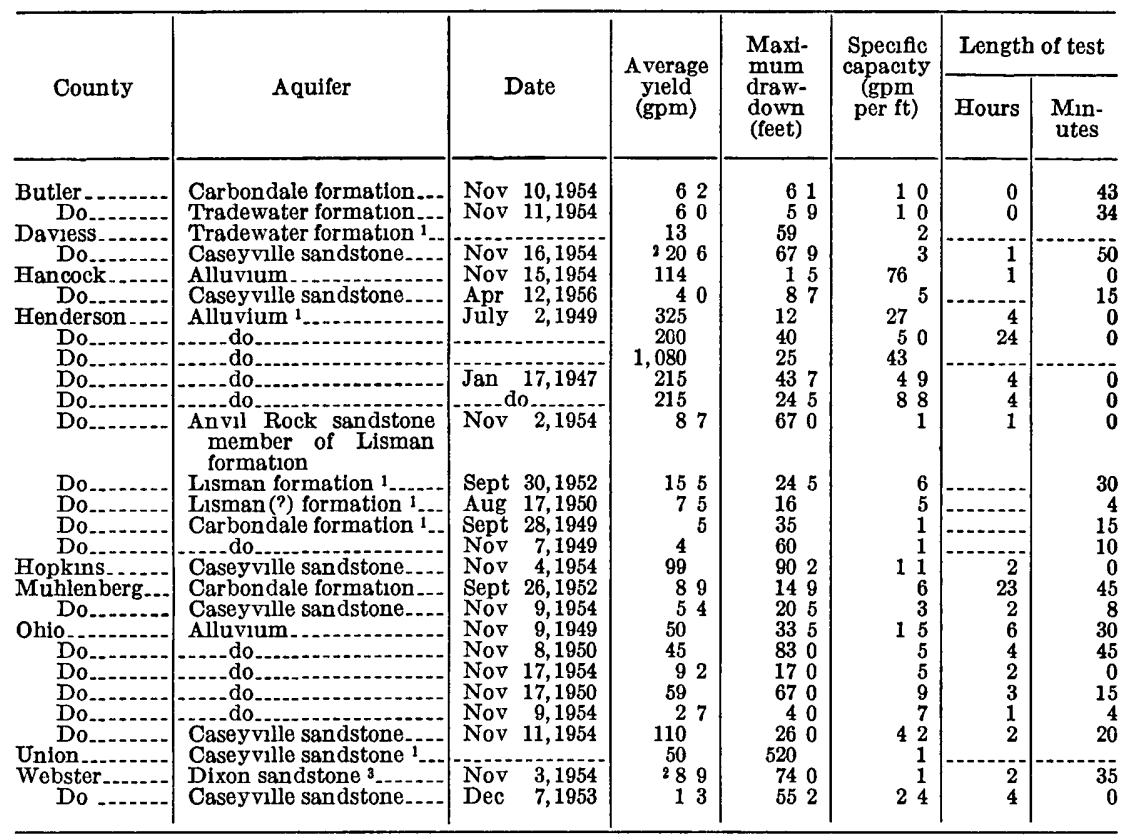

1 Harvey (1956, table 11)

3 Total capacity (see Meinzer, 1923b, p 62 ) 
alluvium and 17 wells in bedrock. Few springs were inventoried in this study, as they form a very minor source of supply in this area. Most yield only very small quantities of water, but some may be adequate for a modern domestic supply. Generally however, the yrelds of the springs fluctuate much more than the yields of wells, and many may be dry durng the late summer and fall. Table 4 shows the correlation of data from 567 drilled wells in bedrock.

\section{Explanation of data for table 4, which is in pocket}

Any two items of well data may be correlated by locating the number in the square formed by the intersection of the column and row of the two items. Each such number is the number of wells in which the two items occur sumultaneously Example. 2 wells are 150 to 300 feet deep and are inadequate; or, of 103 wells that are 150 to 300 feet deep, 2 are inadequate, or of 14 wells that are inadequate, 2 are 150 to 300 feet deep

The sum of all numbers in each large rectangle enclosed by heavy lines is equal to the number of wells in consideration

The sum of each column of numbers in rectangles enclosed by heary lines is in the square at the base of each column

The sum of each row of numbers in rectangles enclosed by heavy lines is in the square to the left of each row

Avallability of ground water in the bedrock depends chiefly on the character, thickness, and depth of the aquifers penetrated and to a limited extent on the topographic situation of the well. Most of the bedrock aquifers in the Western Coal Field region are sandstone. They vary in thickness and composition, and they may thin to a featheredge and disappear in very short distances. They may be friable and highly permeable, or they may contain such large amounts of shale or cementing material that they yield only small amounts of water. In the Western Coal Field region the thickness and character of geologic units may change greatly over short distances. A given unit may be a thick sandstone at one locality, whereas at another point a few miles away it may consist chiefly of shale. Thus, the availability of water in any geologic unit may range widely. The depth to the aquifer largely determunes the cost of drilling the well and may influence the quality of water obtained, inasmuch as saline water is present at depth. The depth to the aquifer also may influence the amount of water obtained if the water occurs in fractures, which generally become smaller with increasing depth. Topography seems to have little effect on the availability of ground water in the Western Coal Field region, except for shallow-water bodies penetrated by dug wells and some shallow drilled wells. Shallow wells on hills are apt to go dry, but most of the drilled wells penetrate below the zonè of water-table fluctuation. 
Of the 567 drilled bedrock wells inventoried, 522, or 92 percent, were less than 300 feet deep. Only 26 were reported inadequate for any purpose or were reported to have gone dry at any time. Figure 8 shows the percentage distribution of yields of 567 drilled wells in bedrock, by depth.

\section{. DETERMINING THE AVATLABILITY OF GROUND WATER AT A GIVEN SITE}

The maps, cross sections, and columnar sections in this report and in the five atlases of the hydrologic investigations series (Maxwell and Devaul, 1962a, b, c, and Devaul and Maxwell, 1962a, b) covering the Western Coal Field region, are designed to indicate the probable avalabllity of ground water at any given site. Determunation of exact conditions in the region is especially difficult because of the great variations in thickness and character of aquifers within short distances. It is obvious that a brief reconnaissance such as that on which this report is based can determine only the probable conditions at any particular site where a well or test hole does not already exist.

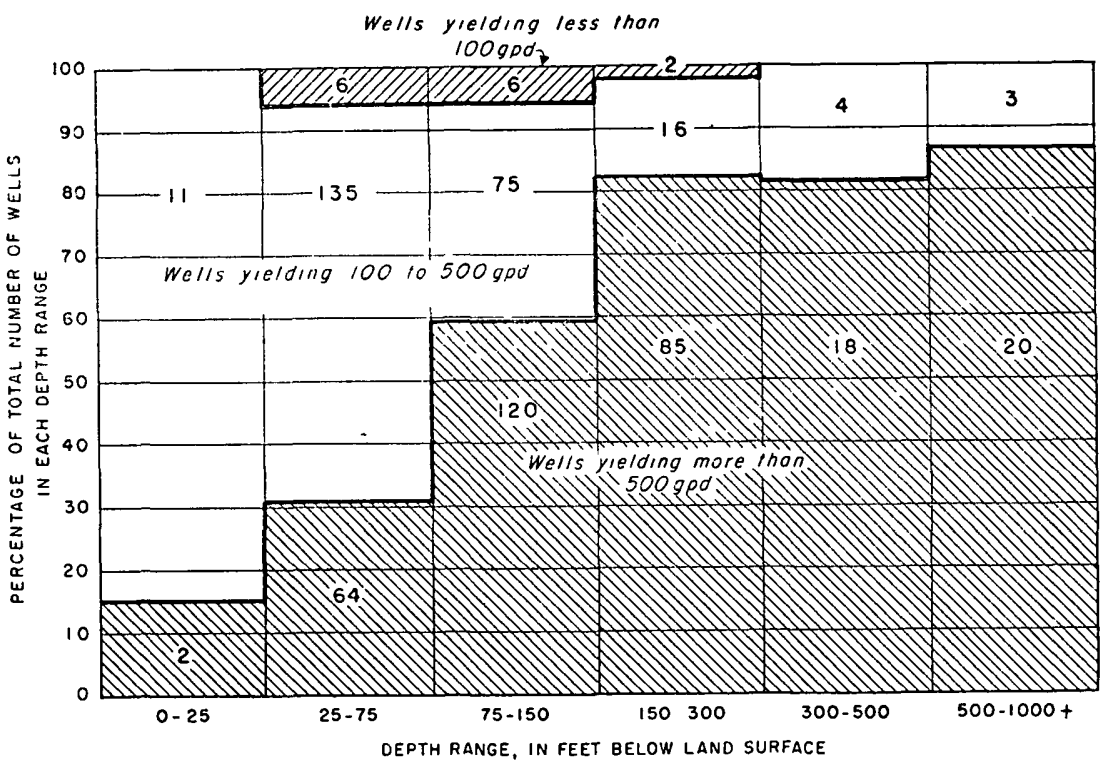

Fiadrm 8-Percentage distribution of ylelds of 567 drilled wells in bedrock, by depth 
A yield of 500 or more is assumed to be sufficient for maximum normal modern household use, as when a power-pump and pressure system are used. A yield of $100 \mathrm{gpd}$ is assumed to be a minimum supply for household use but insufficient for a power-pump and pressure system A yield of less than $100 \mathrm{gpd}$ is assumed to be insufficient for any use.

The region is divided into five areas of ground-water avallability. The areal extent of these subdivisions is shown on the five atlases of the hydrologic investigations series covering the Western Coal Field region.

Area 1 is confined to the Ohio River valley, most of which is underlain by relatively thick sections of sand and gravel that will yield at least $50 \mathrm{gpm}$, or about $70,000 \mathrm{gpd}$, to most wells at depths of less than 150 feet. Many wells will yield several hundred gallons per minute to properly screened wells. Almost all wells in this area will yleld enough water for a modern domestic supply having a powerpump and pressure system (500 gpd or more).

In area 2 most wells yield enough water from depths of less than 300 feet to supply domestic needs where a power-pump and pressure system is used. This area includes the largest part of the bedrock area in the region, some of the alluvium along the Ohio River in which larger yields are not expected, and much of the alluvium along the larger tributaries. Some wells in area 2 will yield enough water for public and industrial supplies; some will not yield enough even for a modern domestic supply.

In area 3 most wells will yield enough water from depths of less than 300 feet to supply domestic needs when a bucket, baller, or hand pump is used (100 to $500 \mathrm{gpd}$ ). This area covers those parts of the region which appear to be underlain by shale, sandy shale, and limestone, and where few wells are known to yield large supplies of water. Even in this area, however, some wells will yield enough water to supply domestic needs when a power-pump and pressure system is used; a few, on the other hand, will not yield even enough for a hand pump, bucket, or baller.

In area 4 most wells fall to supply enough water for domestic use from depths of less than 300 feet; that is, they yield less than 100 gpd. Few wells inventoried fall into this category, and no large areas have been found in which this condition exists Such areas seem to occur only where there are thick sections of unfractured shale and well-cemented sandstone.

In area 5 the yield of wells is unpredictable, commonly because of faulting. 
The avallability maps in the atlases by themselves indicate groundwater conditions in a very general way. However, much better information can be obtained by using the avallability maps in conjunction with the geologic maps, cross sections, and stratigraphic columns included in the atlases and in this report. For example, at Millport, Muhlenberg County, the avallabllity map of Devaul and Maxwell (1962b) indicates that more than half of the wells will yeld enough water for a modern domestic supply at depths of less than 300 feet. Well data on the avallability map show that a dug well at Millport, 23 feet deep and equipped with a power pump, obtains water from the Lisman formation. A drilled well about 2 miles north of Millport, flowing $4 \mathrm{gpm}$, also yields water from the Lisman formation. The geologic map of Devaul and Maxwell (1962b) indicates that the Lisman formation is at the surface in this area, and the geologic section (fig. 5 of that report) indicates that the base of the Lisman is at an altitude of about 175 feet above sea level, or about 240 feet below the land surface. The Lisman formation in this vicinity probably contains a fairly thick sandstone section in its upper part, underlain by interbedded sandstone, shale, coal, and limestone to the base of the formation. The Anvil Rock sandstone member, about 20 feet thick, is near the base of the Lisman The Anvil Rock generally yıelds enough water for a modern domestic supply.

Considering all of the above information, it may be reasonably assumed that a well drilled to a depth of about 100 feet in this place may yield enough water for a domestic supply. If a well 100 feet deep does not yleld enough water, the well can be deepened to penetrate the Anvil Rock sandstone member, which probably will yield additional water Fresh water that is adequate for a large public or industrial supply probably is not avallable in this locality, because the Caseyville sandstone, which is the only other bedrock formation known to yield relatively large supplies in the region, is more than 1,000 feet below the surface Fresh water is rarely obtained from such depths in this region

\section{SUGGESTIONS FOR FURTHER STUDIES}

Additional, more detalled investigations of the avallability of ground water will be needed in different areas as demands for water increase Some of these areas will be determined by the increased need for water by consumers, such as cities and industries, that are already established However, new industries generally will be established in areas where an adequate supply of water is known to 
be avallable. Irrigation of crops, which seems to be increasingly important in Kentucky, also will be stımulated by information on availability of ground water.

Only one area in the Western Coal Field region seems promising as a source of very large supplies of ground water for large cities and industries-the alluvium along the Ohio River flood plain. A more detailed investigation of this area is already underway.

Enough ground water for smaller public supplies and industries may prove to be available from alluvial deposits along the Green River and its major tributaries. Little information is now available on the character of these alluvial materials or the amount of water that may be obtained from them.

As indicated above, the Anvil Rock sandstone member of the Lisman formation and the Caseyville sandstone are known to yield more than $100 \mathrm{gpm}$ in some areas. An investigation to determine additional areas where such yields can be expected may be warranted. The occurrence of fresh water in the Caseyville at depths approaching 1,000 feet is of partıcular interest.

Saline water, which is unsuitable for most uses, is being used in places for water drive in the secondary recovery of oil. An investigation of the availability of this water would be of considerable interest to the oil industry of the region

\section{METHODS OF OBTAINING GROUND WATER}

\section{SPRINGS}

Few springs were inventoried in the Western Coal Field region, as they are a minor source of water. Of the springs inventoried, probably most would not supply enough water for domestic use where a power-pump and pressure system was used. However, if adequate storage is provided, some of the springs may yield enough for such use.

\section{DUG WELIS}

In some areas dug wells are a common source of water. Where water from deeper aquifers is not obtainable or is of poor quality, dug wells or cisterns must be used. Because most dug wells are shallow and penetrate only a short distance below the water table, they are apt to go dry in dry weather. Only a few of the dug wells inventoried would produce enough water for a modern domestic supply. Unless properly constructed, dug wells are easily contaminated from surface sources. 


\section{DRILIED WEITS}

In the Western Coal Field region most wells are drilled. Most of those inventoried were drilled by the cable-tool method, although a fow in alluvium were drilled by the rotary method.

Most of the wells in bedrock are only 6 inches in diameter. Some, which furnish industrial or public supplies, are as much as 12 inches in diameter. The wells are commonly cased down to bedrock but may be cased a considerable distance into the bedrock. If the aquifer occurs below a coal bed, the casing may be driven down below the coal. If a soft shale is penetrated before reaching the aquifer, the casing may be driven through the shale to prevent the collapse of the hole.

Wells drilled into alluvium generally have a screen as part of the casing. The type of material and size of openings of the screen should be determined after study of drill cuttings and analysis of a water sample.

Driven wells are common in the alluvium. Most are $11 / 4$ to 2 inches in diameter. They range in depth from about 25 feet to a reported 99 feet, although most are less than 40 feet deep. Several 4-inch driven wells have been installed to obtain water for irrigation.

\section{QUALITY OF WATER}

Figure 9 shows the quality of water in the region by means of bar diagrams based on the median values of several constituents determined by partial and comprehensive chemical analyses of water samples from different aquifers. Because median values of large groups are used, the anion and cation bars of the composite analysis for each aquifer do not agree. Median values are used in preference to averages in order to offset very high values of dissolved solids in some samples which are not typical. Table 5 is a summary of comprehensive analyses of ground water, by formation, in the Western Coal Field, and table 6 describes the significance of dissolved mineral constituents and physical properties of natural water.

The water in the shallow bedrock aquifers of the region generally is of the sodium bicarbonate or the calcium bicarbonate type. At greater depths the calcium bicarbonate water becomes less common, and the water usually is more highly mineralized and is of the sodium bicarbonate or sodium chloride type Almost all the sodium chloride water is too highly mineralized for domestic use. Saline water has been found at depths as shallow as 100 feet, but fresh water has been obtained from the Caseyville sandstone at depths approaching 1,000 feet. Water from the bedrock generally is soft to moderately hard, but it may contain undesirable amounts of iron. 


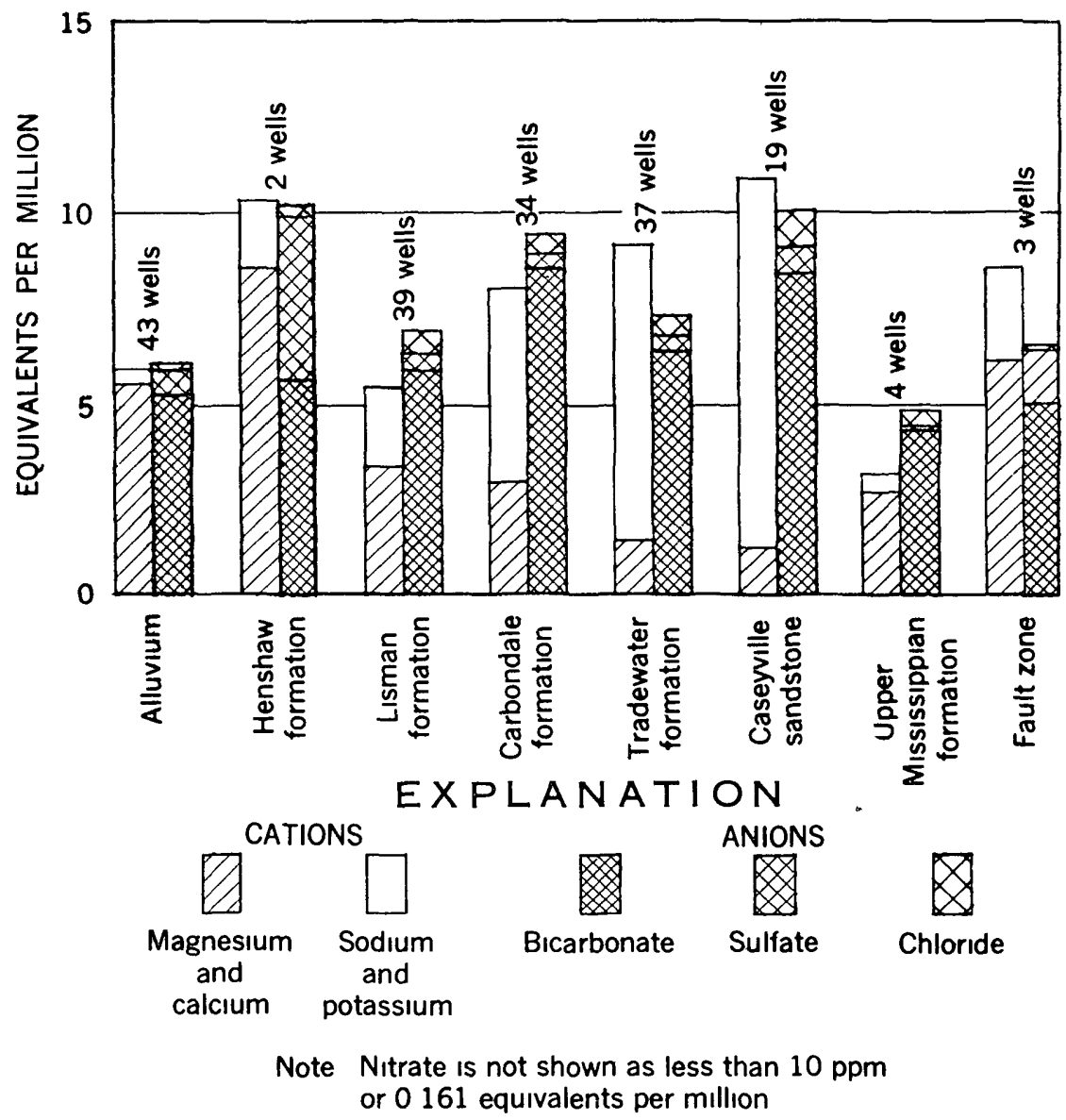

FIGURE 9 -Graphs showing median values of dissolved constituents in ground water, by aquifers 
TABLE 5-Summary of analyses of ground water in the Western Coal Field region, Kentucky [Analyses by U S Geological Survey Dissolved constituents given in parts per millon]

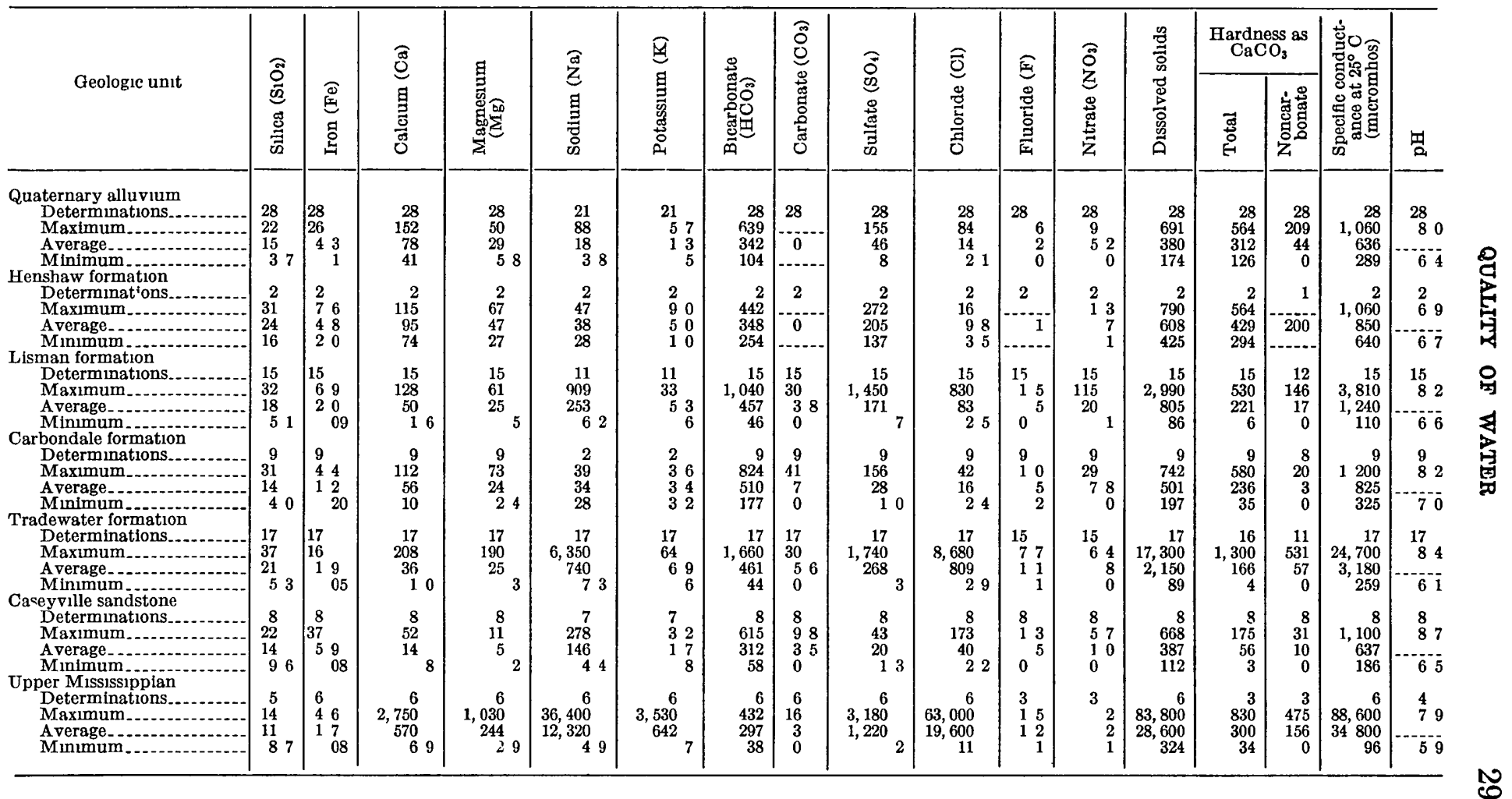


TABLE 6-Significance of dissolved mineral constituents and physical properties of natural water

Constituent or phystcal property

Silica $\left(\mathrm{SiO}_{2}\right) \ldots \ldots . . . . .$.

Iron $(\mathrm{Fe})$

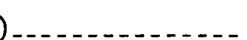

Dissolved from practically all rocks and soils, usually in small amounts, 1-30 ppm High concentrations, as much as $100 \mathrm{ppm}$, generally are found in highly alkaline water

Dissolved from practically all rocks and solls May be derived also from iron pipes, pumps, and other equipment More than 1 or $2 \mathrm{ppm}$ of soluble iron in surface water usually indicates acid wastes from mine drainage or other sources

Manganese (Mn) .........

Dissolved from some rocks and solls Not so common as iron Large quantities often associated with high iron content and with acid water

Calclum (Ca) and magnesium $(\mathrm{Mg})$

Sodium $(\mathrm{Na})$ and potasslum (K) stone, dolomite, and gypsum Calclum and magnesium are found in large quantities in some brine Magnesium is present in large quantities in sea water

Dissolved from practically all rocks and sols Found also in ancient
Significance

Forms hard scale in pipes and bollers Calried over in steam of high-pressure bollers to form deposits on blades of steam turbines Inhibits deterioration of zeolite-type water softeners

On exposure to air, iron in ground water oxıdizes to reddısh-brown sediment More than about $03 \mathrm{ppm}$ stains laundry, utensils, and fixtures reddish-brown Objectionable for food processing, beverages, dyeing, bleaching, ice manufacture, brewing, and other processes Federal drinkıng-water standards (U S Public Health Service, 1946) state that iron and manganese together should not exceed $03 \mathrm{ppm}$ Larger quantities cause unpleasant taste and favor growth of iron bacteria

Same objectionable features as iron Causes dark-brown or black stain Federal drinking-water standards provide that iron and manganese together should not exceed $03 \mathrm{ppm}$

Cause most of the hardness and scale-forming properties of water, soap-consuming (See Hardness) Water of low calclum and magnesium content are desired in electroplating, tanning, dyeing, and textlle manufacturing brine, sea water, some industrial brine, and sewage

Large amounts, in combination with chloride, give a salty taste Moderate quantities have little effect on the usefulness of water for most purposes Sodium salt may cause foaming in steam bollers and a high sodium ratio may limit the use of water for irrigation 
Bicarbonate $\left(\mathrm{HCO}_{3}\right)$ and carbonate $\left(\mathrm{CO}_{3}\right)$

Sulfate $\left(\mathrm{SO}_{4}\right)$

Dissolved from rocks and solls containing gypsum, iron sulfides, and other sulfur compounds Usually present in mine water and in some industrial wastes

Chloride (Cl)

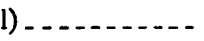

Dissolved from rocks and solls Present in sewage and found in large amounts in ancient brine, sea water, and industrial brine

Fluoride (F) Dissolved in small to minute quantities from most rocks and solls

Nitrate $\left(\mathrm{NO}_{8}\right)$

Orıgınates in decayıng organic matter, including sewage, and nitrate fertilizers
Bicarbonate and carbonate produce alkalinity Bicarbonates of calcium and magnesium decompose in steam bollers and hotwater facilities to form scale and release corrosive carbon dioxide gas In combination with calcium and magnesium cause carbonate hardness

Sulfate in water containing calcium forms hard scale in steam boilers In large amounts, sulfate in combination with other ions gives bitter taste to water Some calcium sulfate is considered beneficial in the brewing process Federal drinking-water standards recommend that the sulfate content should not exceed 250 $\mathrm{ppm}$

In large amounts in combination with sodium gives salty taste to drinking water In large quantities increases the corrosiveness of water Federal drinking-water standards recommend that the chloride content should not exceed $250 \mathrm{ppm}$

Fluoride in drinking water reduces the incidence of tooth decay when the water is consumed during the period of enamel calcifieation However, when consumed regularly by children it may cause permanent mottling of the tooth enamel, according to the concentration of fluoride, age of the child, amount of drinking water consumed, and susceptibility of the individual (Maier, $1950, \mathrm{p} 1120-1132$ )

Concentrations much greater than the local average may suggest pollution There is evidence that more than about $45 \mathrm{ppm}$ of nitrate $\left(\mathrm{NO}_{3}\right)$ may cause a type of methemoglobinemia ("blue baby" disease) in infants, sometimes fatal Water of high nitrate content should not be used in baby feeding (Maxcy, 1950, p 265, app D) Nitrate has been shown to be helpful in reducing intercrystalline cracking of boller steel It encourages growth of algae and other organisms which produce undesirable tastes and odors 
Constituent or physical property

Dissolved solids.

Hardness as $\mathrm{CaCO}_{3 \ldots} \ldots$

Chiefly mineral constituents dis-
solved from rocks and solls Includes any organic matter and some water of crystallization

Nearly all the hardness of most water is due to calcuum and magnesium All the metallic cations other than the alkalı metals also cause hardness, as does free acid

Specific conductance (ml- Mineral content of the water...... cromhos at $25^{\circ} \mathrm{C}$ )

IIydrogen-ron concentration (expressed as $\mathrm{pH}$ )

Temperature

Acids, acıd-generating salts, and free carbon dioxide lower the $\mathrm{pH}$ Carbonate, bicarbonate, hydroxide, phosphate, sllicate, and borate raise the $\mathrm{pH}$
Significance

Federal drinking-water standards recommend that the diss jlved solids should not exceed $500 \mathrm{ppm}$ Water containing more than $1,000 \mathrm{ppm}$ of dissolved solids is unsuitable for many purposes

Consumes soap before a lather will form Deposits soap curd on bathtubs Hard water forms scale in bollers, water heaters, and pipes Hardness equivalent to the bicarbonate and carbonate is called carbonate hardness Any hardness in excess of this is called noncarbonate hardness Water having a hardness up to $60 \mathrm{ppm}$ is considered soft, 61 to $120 \mathrm{ppm}$, moderately hard, 121 to $200 \mathrm{ppm}$, hard, and more than $200 \mathrm{ppm}$, very hard

Specific conductance is a measure of the capacity of the water to conduct an electric current, it varies with concentration and degree of conization of the constituents Varies also with temperature, reported at $25^{\circ} \mathrm{C}$

A pH of 70 indicates neutrality of a solution Values higher than 70 denote increasing alkalinity, values lower than 70 indicate increasing acidity $\mathrm{pH}$ is a measure of the activity of the hydrogen ions Corrosiveness of water generally increases with decreasing $\mathrm{pH}$ However, excessively alkalıne water also may attack metals

Affects usefulness of water for many purposes For most uses, water of uniformly low temperature is desired Shallow wells show some seasonal fluctuations in water temperature Ground water from moderate depths usually is nearly constant in temperature, which is near the mean annual air temperature of the area In very deep wells the water temperature generally increases about $1^{\circ} \mathrm{F}$ with each 50 to 100 feet of increased depth Seasonal fluctuations in temperatures of surface water are comparatively large but do not reach the extremes of an temperature 
Water from the alluvium is generally of the calcium bicarbonate type and is generally harder and contains more iron than water from the bedrock. However, water from most wells in the alluvium is suitable for domestic use. No salıne water was reported from any of the wells in alluvium.

\section{SELECTED REFERENCES}

Burroughs, W G, 1924, Geography of the Western Kentucky Coal Field Kentucky Geol Survey, ser 6, v 24, $211 \mathrm{p}$.

Cathey, J B., Jr, 1955, Geology and mineral resources of the Newburgh quadrangle, Kentucky Kentucky Geol Survey Bull 15, ser 9, $51 \mathrm{p}$

Chisholm, D B, 1931, The geology of Hancock County, Kentucky. Kentucky Geol Survey, ser 6, v. 41, p 217-247

Crider, A F, 1913, Economic geology of Tell City and Owensboro quadrangles Kentucky Geol Survey, ser 4, v 1, pt 1, p 262-316.

1915, The coals of the Little Muddy quadrangle: Kentucky Geol Survey, ser 4, v 3, pt 1, p 173-175.

Devaul, $\mathbf{R}$ W and Maxwell, B W, 1962a, Avalability of ground water in Daviess and Hancock Counties, Kentucky . U S Geol. Survey Hydrol Inv Atlas HA-27, in press.

- 1962b, Avalability of ground water in McLean and Muhlenberg Counties, Kentucky U S Geol Survey Hydrol. Inv Atlas HA-29, in press.

Eardley, A J , 1951, Structural geology of North America: New York, Harper \& Bros, $624 \mathrm{p}$

Freeman, L B, 1951, Regional aspects of Silurian and Devonian stratigraphy in Kentucky Kentucky Geol Survey Bull 6, ser. 9, 561 p

Gardner, J H, 1927, The Elm Lick coal bed: Kentucky Geol. Survey, ser 6, จ. 26, p 129-154.

Glenn, L C, 1912, A geological reconnaissance of the Tradewater River region, with special reference to the coal beds. Kentucky Geol. Survey Bull 17, 75 p. 1922, The geology and coals of Webster County: Kentucky Geol. Survey, ser $6, v 5,249 \mathrm{p}$

Guyod, Hubert, 1952, Electrical well logging fundamentals: Houston, Tex, Well Instrument Developing Co, $164 \mathrm{p}$

Harvey, E J , 1956, Geology and ground-water resources of the Henderson area, Kentucky: U S Geol Survey Water-Supply Paper 1356, 227 p

Hutchinson, F M, 1912, Report on the geology and coals of the Central City, Madisonville, Calhoun, and Newburg quadrangles, in Muhlenberg, Hopkins, Ohı, McLean, Webster, Daviess, and Henderson Counties: Kentucky Geol. Survey Bull. 19, $127 \mathrm{p}$

Leverett, Frank, 1929, Pleistocene of northern Kentucky · Kentucky Geol Survey, ser $6, \mathrm{v} 31, \mathrm{p} \mathrm{1-80}$

McFarlan, A C, 1950, Geology of Kentucky . Lexıngton, Unıv. Kentucky, 531 p

Marer, F J, 1950, Fluoridation of public water supplies Am Water Works Assoc Jour, v 42, pt 1, p 1120-1132

Maxcy, K. F, 1950, Report on the relation of nitrate concentration in well waters to the occurrence of methemoglobinemia: Natl. Research Councll Bull Sanitary Eng and Environment, app D

Maxwell, B W., 1954, Public and industrial water supplies of the Western Coal region, Kentucky U S Geol Survey Crrc 339, 41 p 
Maxwell, B W, and Devaul, R W, 1962a, Avallabulity of ground water in Butler and Ohio Counties, Kentucky US Geol Survey Hydrol Inv Atlas HA-26, in press.

1961b, Avalability of ground water in Union and Henderson Counties, Kentucky U S Geol Survey Hydrol Inv Atlas HA-30, in press

- 1962c, Avallability of ground water in Hopkıns and Webster Counties, Kentucky. U S Geol. Survey Hydrol. Inv. Atlas HA-28, in press.

Mayfield, S. M., 1934, Geology of Fordsville and Cannelton quadrangles Chicago, Unıv. Chicago libranes, $181 \mathrm{p}$.

Meinzer, O E, 1923a, The occurrence of ground water in the United States, with a discussion of principles US Geol Survey Water-Supply Paper 489, $321 \mathrm{p}$

1923b, Outlıne of ground-water hydrology, with definitions U S Geol Survey Water-Supply Paper 494, $71 \mathrm{p}$

Norwood, C J , 1876, Report on the geology of the region adjacent to the Loussville, Paducah, and Southwestern Rallroad Kentucky Geol Survey Prog Rept 1, new ser, p 355-448

Owen, D D, 1856, Report of the geological survey of Kentucky made during the years 1854 and 1855 Kentucky Geol Survey, v 1, p 60-61

Robinson, L C , 1931, A reconnaissance report on the geology of McLean County Kentucky Geol Survey, ser 6, v 37, p 303-324

Sısk, A D, 1954, Annual report Lexıngton, Kentucky Dept Mınes and Mınerals, $165 \mathrm{p}$

U S Public Health Service, 1946, Drınkıng water standards Public Health Service Repts, $\mathrm{v}$ 61, no 11, p 371-384

Walker, E H, 1957, The deep channel and alluvial deposits of the Ohio Valley in Kentucky U S Geol Survey Water-Supply Paper 1411, 25 p

Walker, F H, Puryear, R E, and Cathey, J B, Jr, 1951, Geology and mineral resources of the Henderson quadrangle, Kentucky Kentucky Geol Survey Bull 7, ser 9, $32 \mathrm{p}$

Wanless, $H$ R, 1929, Geology and mineral resources of the Alexis quadrangle Illınors Geol Survey Bull 57, p 90-91

- 1939, Pennsylvanıan correlations in the Eastern Interior and Appalachian Coal Fields Geol Soc America Spec Paper 17, $130 \mathrm{p}$

Wilmarth, M G, 1930, Tentative correlation of named geologic units of Kentucky U S Geol Survey open-file report 


\section{Maxwell, Bruce William, 1925-}

Reconnaissance of ground-water resources in the Western Coal Field region, Kentucky, by B. W. Maxwell and R. W. Devaul. Washıngton, U.S. Govt. Print. Off., 1961.

1v, $34 \mathrm{p}$ maps (part col) diagrs, tables $24 \mathrm{~cm} \quad$ (U S Geological Survey (Water-supply paper 1599)

Part of illustrative matter in pocket

Prepared in cooperation with the Commonwealth of Kentucky, Dept of Economic Development, and the Kentucky Geological Survey, Unıversity of Kentucky

Biblography . p 33-34

(Continued on next card)

\section{Maxwell, Bruce William, 1925-}

Reconnalssance of ground-water resources in the Western Coal Field region, Kentucky. 1961. (Card 2)

1 Water, Underground-Kentucky-Western Coal Field region 2 Water-supply-Kentucky-Western Coal Field region 3. Water-Composition I Devaul, Robert Washburn, 1918-, joint author II Kentucky Dept of Economic Development III Kentucky Geological Survey IV Title Western Coal Field region, Kentucky (Series) 